\title{
Efforts to Improve the Ability of The Teachers in Development Program for Strengthening Character Education (PPK) in Early Childhood Education (ECE) through Workshop Activities
}

\author{
Eny Nur Aisyah \\ Early Childhood Departmen \\ Universitas Negeri Malang \\ Malang, Indonesia \\ eny.nur.fip@um.ac.id
}

\author{
Achmad Samawi \\ Early Childhood Departmen \\ Universitas Negeri Malang \\ Malang, Indonesia \\ achmad_samawai@yahoo.co.id
}

\author{
Ajeng Fitri Untariana \\ Early Childhood Departmen \\ Universitas Negeri Malang \\ Malang, Indonesia \\ ajenguntariana@gmail.com
}

\begin{abstract}
The government is carrying out the construction and development of character education in an effort to strengthen mental revolution movement in early childhood education. Strengthening character education is carried out through educational practices carried out in an integrated manner in children's teaching and learning activities. Early Childhood Education (ECE) Institutions must have a special program in implementing the Character Education Strengthening (PPK) program, so training and workshops are needed. The workshop was intended to increase the insight and ability of teachers in preparing PPK. The method used in the workshop activities was a discussion, information sharing and training with the andragogy approach. The results of the workshop, the participants have increased knowledge and ability in preparing the PPK program in schools.
\end{abstract}

Keywords- strengthening character education, early childhood education, workshop activities

\section{INTRODUCTION}

ECE is an institution that becomes the basis for the formation of character in children. Based on observations, there are still many ECE institutions that do not have a special program in the implementation of character education practices. This is one of the factors why this workshop was held. ECE is an institution that became the basis for instilling the value of the character. But in practice, there are still many learning activities conducted by teachers that focus only on cognitive activities. The teacher still has not implemented effective learning (character) in the process of teaching and learning activities. Based on the observations found, it is necessary to help PAUD educators through technical guidance in the form of workshops and assistance.

In the KDP program prepared in accordance with government policy. This policy, namely the Government Regulation Number 87 of 2017 concerning Strengthening Character Education which states that in order to realize a cultured nation through the values of religious character, honesty, tolerance, discipline, hard work, creative, independent, democratic, curiosity, the spirit of achievement, communicative, love of peace, love of reading, caring for the environment, caring socially, and being responsible.

The 2013 curriculum which is a reference in the preparation of current learning plans tends to be constructivist, competency based, active learning, and based on the values of 21 st-century life. The 2013 curriculum is intended to prepare the next generation of the nation with good character and ready to face the challenges of life in the 21 st century. This is in line with the Character Education Strengthening program which is carried out through movement bases, namely learning in class, school culture, management or governance, and community participation by pivoting on five main values including religious, nationalist, mutual cooperation, integrity, and independence. The five main values are described as follows.

Religious consists of peaceful love, tolerance, respect for differences, determination, confidence, cooperation between adherents of religion and belief, no bullying and violence, friendship, sincerity, not imposing will, love for the environment, protecting the small and excluded. Nationalist consists of appreciation of their own culture, maintaining their own national culture, sacrifice, excellence, achievement, love of the homeland, protecting the environment, law-abiding, self-discipline, respect for cultural diversity-ethnic-religious. Independent consists of values of hard work, tough, resilient, fighting the power, professional, creative, courage, lifelong learning. Mutual cooperation consists of cooperation, respect, inclusiveness, commitment to the decision together, consensus, mutual help, solidarity, empathy, not discrimination-violence, and the attitude of volunteerism. Integrity consists of honesty, love of truth, faithfulness and moral commitment, not corruption, justice, responsibility, exemplary, respect for dignity. Characters in early childhood education cannot be implemented in isolation but must be integrated with the learning process in an integrated manner. The principle of integrated learning, which is holistic, authentic, active, and meaningful. This principle should be a guide in learning about the value of characters in the class. The fundamental principle in the implementation of integrated learning according to Kovalik [2] is to present "meaningful content."

Meaningfulness in a learning process can occur by considering the following factors, including: (1) the content of learning is lifted from the reality of life and nature around children; (2) associated with children's perception; (3) cooperative learning: (4) done in a variety of ways; (5) things obtained in the learning process have a function for the child's life; and (6) do not require external rewards. Another factor that also needs to be considered is to provide choices for students. Students do not learn in the same way. There is 
no way that can equalize children's learning outcomes because learning outcomes will develop according to the needs of students. Educators should facilitate all the intelligence of students according to Howard Gardner [3], namely logical-mathematical, spatial-visual, kinesthetic, musical, intrapersonal, interpersonal, naturalist, and existential.

Early childhood educators to integrate characters learning must uphold honesty, active listening, giving children the opportunity, not degrading, and create a trust [2]. Educators should also apply moral leadership which is marked by the integration of beliefs with words and actions in the learning process. Technical implementation of PPK in integrated learning is as follows: (1) reconstructed the learning tools that will be made; (2) presenting character values in every area of child development aspects that are focused on the core values of each of these fields [4]; (3) view students as students; (4) become a teacher who serves as a moral leader; (5) start learning by praying and praying that they can study through motivational and inspiring sentences; (6) arranging the socio and psychological situation of learning in accordance with certain themes that allow children to easily communicate, collaborate, and work together; (7) presenting character values through various sources or learning media; (8) implementing Active Learning that is child-oriented; (9) accelerate the process of internalization of values (character) with learning that involves "understanding, feeling, doing" (Dewantara, 1933), Knowing, Feeling, Action "(Lickona, 1992); Thought, Dhikr, Effort "[5], and Understanding, Action, Reflection" (Bohlin, 2001); and (10) conducting autentic assessment which serves as "feedback" to strengthen the character of children, then ending learning by prayer and praying for requests for good character and giving moral messages.

PPK based on school culture is done through habituation by instilling the main values in routine, incidental, and programmed activities. The habituation by Akbar [6] is what determines the behavior of students. Student behavior can also be formed through exemplary, structuring the school environment, traditions, work and activities in school. Other steps that can be taken in implementing the culture-based PPK are: facilitating the development of potential students; reconstruction of vision and mission and school branding; reconstruct various disciplines for students, teachers, principals, parents, and other school residents who are oriented towards the main values; and structuring the physical, social and psychological situation so as to create a conducive school life culture.

PPK based on school governance can be supported by instilling the main values of PPK that are carried out in an integrated, collaborative and synergistic manner. At the education unit level, PPK involves school principals or foundation leaders, educators, education personnel, school committees, community communities and professional organizations, business and industry, mass media, alumni ties, universities and others [7]. The PPK is carried out with good planning, organization, movement, and control, as well as evaluating activities and programs.

Community-based PPK done by involving the community, the community of parents, community arts and cultural center, health center BNN- government agencies, and others. This community-based PPK can be implemented through programs with families, programs with institutions such as health centers, joint programs of professional groups such as farmers, farmers, police and so on, social action programs such as supporting orphans, competent programs through competitions involving many children [7].

\section{METHOD}

The PPK program programming and training activities were carried out through training methods using various information, sharing or discussion and ended with workshops. The approach used in this activity is the andragogy approach. The andragogy approach was chosen because workshop participants were adults. Workshop conducted by three (3) stages: (1) perform PPK training with the basic concept of training materials PPK, PPK-Based Classroom, School of Culture-Based PPK, PPK-Based Public Participation and Governance Based PPK and PPK Evaluation; (2) workshop preparation PPK program in early childhood education units, with each unit targets ECE produces PPK; and (3) perform PPK program review every unit produced early childhood education, guided by a team of facilitators that can produce PPK program is good and ready to be implemented in each unit ECE.

The first stage, perform PPK training with training materials including basic concepts PPK, PPK-Based Classroom, School of Culture-Based PPK, PPK-Based Public Participation and Governance Based PPK and PPK evaluation. Basic concepts of $\mathrm{CO}$ exposure conducted by a team of lecturers of ECE teacher education State University of Malang. The material presentation began with an explanation of the government's policy on character education from 2010 to 2017 about strengthening character education. There are five main values in strengthening character education, namely Religious, Nationalist, Independent, Mutual Cooperation and Integrity.

The next presentation in this first stage is about ClassBased PPK. Class-Based PPK implemented by integrating the PPK through a curriculum, the content of learning, classroom management, teaching methods, authentic assessment, reflection and moral messages, literary movements, and guidance and counseling services. This Class-Based PPK is closely related to classroom learning. Learning in class is an effort by educators to facilitate students by making it easy for students to learn easily. Learning is a system that is carried out by combining various learning sub-systems. The sub-systems referred to students, educators, curriculum, learning objectives, learning resources and media, learning environments and learning evaluations.

PPK -Based Public Participation implemented by involving the public, the community of parents, community arts and cultural center, health center BNN government agencies, and others. This community-based PPK can be carried out through programs with families, programs with institutions such as health centers, joint programs of professional groups such as farmers, breeder, police and so on, social action programs such as supporting orphans, competent programs through competitions involving many children.

School Culture-Based PPK is carried out through habituation by instilling key values in routine, incidental, and programmed activities. The habituation by Akbar [6] is what determines the behavior of students. Student behavior can also be formed through exemplary, structuring the school 
environment, traditions, work and activities in school. Other steps that can be taken in implementing the culture-based KDP are: facilitating the development of potential students; reconstruction of vision and mission and school branding; reconstruct various disciplines for students, teachers, principals, parents, and other school residents who are oriented towards the main values; and structuring the physical, social and psychological situation so as to create a conducive school life culture.

PPK Based on School Governance can be supported by instilling the main values of PPK that are carried out in an integrated, collaborative and synergistic manner. At the level of the educational unit, PPK involving the principal or head of the foundation, educators, staff, school committee, community and professional organizations, business and industry, the media, alumni associations, universities and other [7]. The PPK held with the planning, organization, movement, and good control, and evaluate activities and programs. PPK is assessed by the school by involving related parties (education stakeholders). Rating success PPK that objectively it must be done with a minimum of three stakeholders of education, the school, parents (school committee), and supervisors. The evaluation was done by assessing the PKK's success in utilizing the information from the assessment rubric as a tool to help justify the PPK's indicator.

The presentation of the basic concept in the first stage has a purpose to provide workshop participants with an overview of PPK basis. At this stage, it is hoped that it can add insight and knowledge to the workshop participants and experts in preparing the PPK program in ECE. At this stage apply information sharing methods and question and answer in their implementation.

The second stage is the preparation of the KDP program of workshops conducted by the participants in a group containing three people in each group. Groups are formed based on the origin of the institution. The workshop was attended by 21 teachers, so there were 7 groups in the workshop activities. The second stage has a purpose to train workshop participants to be able to develop PPK programs that are in accordance with the guidelines and adapted to the characteristics of each school. At this stage use discussion and workshop methods.

The components described by the workshop participants are as follows; (a) Class-Based PPK, namely number, form of activity, purpose of activities, character value, partners and community involved in learning activities, and implementation time; (b) PPK Based on School Culture, namely the format for preparing branding school and developing habituation activities. The components described in the preparation of branding school are the vision and mission of the school, the main values of PPK, the potential of the school environment that can support the PPK program, the uniqueness of schools, the excellence of schools, the weaknesses of schools with SWOT analysis, and creating branding schools that will be developed. Components described in the development of habituation activities include: routine school activities, school programmed activities, and incidental activities of schools; (c) PKK Based on Community Participation, namely the main values of the characters that want to be developed together with the community, the forms of cooperation activities that will be established by schools, determine the communities that may be involved, and the form of community participation in PPK activities in schools; (d) PPK Based on School Governance and Management, namely the vision and mission of the school, the purpose of the school, the main value of the PPK to be developed, the uniqueness that characterizes the school, analyzes the strengths and weaknesses of the school using SWOT analysis, selection of branding school and providing reasons for selection the branding. The preparation of program evaluation must pay attention to the form of activities of each PPK program base in schools.

The third stage is a review of the PPK program produced by each ECE unit with the guidance of a lecturer team so as to produce a good PPK program that is ready to be implemented. The third stage aims to review the program and make the provision of input into the corrective action program. At this stage use the discussion method in its implementation.

\section{RESULT}

This workshop activity not only resulted in increased knowledge and knowledge of workshop participants, but also successes in the preparation of Class-Based PPK programs, School Culture Based PPK, PPK Based on Community Participation, PPK Based on School Governance and Management, and school program evaluations. Schools that have successfully compiled the PPK program include UM Laboratory Kindergarten, Muslimat NY Kindergarten, ABA Kindergarten, Madani Insan Kindergarten, As-Salam Kindergarten, Satu Atap Kindergarten, and UM Day Jasmine Care. However, there is one school that has compiled a PPK program in accordance with the plans expected by the government.

This can also be seen based on the comparison of the results of the pre-test with the post-test that has been carried out to find out the teacher's knowledge of the PPK program described in the graph as follows.

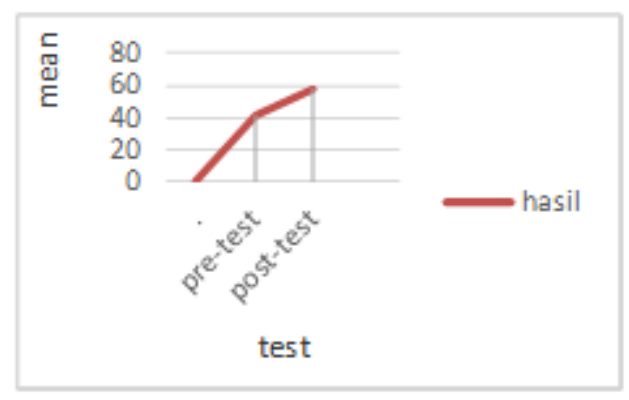

Fig. 1. Graph of Workshop Participants' Knowledge of the PPK Program

The graph above shows that many teachers did not understand the PPK program before participating in the workshop activities, it was seen in the pre-test results of the workshop participants, namely getting an average score of 40. The increase in value occurred in the post-test results, which increased with the average score. average 60 and all participants can produce Class-Based PPK programs, School Culture Based PPK, Community Participation PPK, PPK Based on School Governance and Management, and school program evaluations that are in accordance with government guidelines. Based on these results it can be concluded that PPK training participants and workshops in ECE experienced improved insight and produced PPK programs that were in accordance with government guidelines. 


\section{DISCUSSION}

The character is a behavior that is reflected in a person's personality into behavior that is typical of individuals formed from individual manifestations with environmental factors in both social and natural environment. While character education is an effort made by educators to students to be able to understand the values held in society.

Strengthening character education must be carried out in a long and continuous period. Strengthening can be done starting from the nearest environment to a wider environment. Strengthening will be done to shape the character of students who are integrated through the process of internalization and personalization of each individual. Strengthening can also be carried out in various efforts such as structuring the learning environment in formal and nonformal education units. Various awards also need to be given to formal and non-formal education units, educators, education personnel, and students to further strengthen the encouragement, invitation, and motivation for character development [8]

Character education must be applied in the implementation of learning including Early Childhood Education (ECE) which is the foundation and basis for the child's character in the future. The understanding of the teacher regarding character education is very important to maximize the process of planting character education in the educational environment in the learning process. Workshops and training are one of the activities to improve the knowledge and skills of ECE educators in preparing the PPK program in schools.

The PPK program carried out in the workshop activities needs to pay attention to the principles of training implementation activities so that it can lead to active and participatory involvement of trainees. The principles of implementing these activities include: (1) the active involvement of the participants so that they can get the opportunity to express their opinions and experiences; (2) the comfort of participants during activities such as seating, lighting, and material presentation so that all trainees can see and understand them; (3) Focus on the goals that mean the facilitator needs to focus on one thoroughly designed activity from beginning to end so that the purpose of training can be achieved optimally; (4) Attention to the dynamics of the participants, namely the facilitator needs to get used to having the accuracy and understanding of the dynamics of the participants so that it can run in line with expectations, (5) opinion documentation, meaning that the facilitator needs to record the opinions of the active participants both during evaluation and reflection. (6) an action plan, that is, each implementation of training activities will end with the writing of an action plan to strengthen participants' understanding of the activities to show that participants understand the purpose of the training [7].

The workshop activities and PPK program preparation training for ECE educators in addition to being able to produce increased knowledge and knowledge of workshop participants were also successful in the preparation of ClassBased PPK programs, School Culture Based KDP, Community Participation PPK, PPK Based on School Governance and Management, and program evaluation school.

\section{CONCLUSION}

The implementation of the PPK program preparation workshops and training focused on the development of ECE teacher knowledge as well as the preparation of Class-Based PPK programs, School Culture Based PPK, Community Participation PPK, PPK Based on School Governance and Management, and School Program Evaluation. The pre-test results conducted to find out the teacher's initial knowledge about the PPK program showed that there were still many teachers who did not understand the PPK program, it was seen in the pre-test results of participants with an average score of 40, while the post-test conducted was found results with an average score of 60 . All participants can produce PPK program products that are in accordance with government guidelines so that it can be concluded that PPK training participants and workshops in ECE experienced increased insight and produced PPK programs.

Research into the practice of character education has been carried out nationally and comprehensively. The limitation in this study is the time for short data collection so that researchers can only reach predetermined respondents. Based on the results of this study, it is expected that the researcher can further increase the respondents so that the insight gained is broader. The education unit can also synergize to create character education practices in an effort to create national children with good character in accordance with the ideals of the nation.

\section{REFERENCES}

[1] Kemendikbud. 2017. Konsep dan Pedoman Penguatan Pendidikan Karakter. Jakarta: Pusat Analisis dan Sinkronisasi Kebijakan Sekretariat Jenderal Kementrian Pendidikan dan Kebudayaan.

[2] Kovalik,S. 1994. Integrated Thematic Instruction (IT), Third edition. Washington: Susan Kavolik \& Associates

[3] Gardner, Howard. 1993. Multiple Intelligences The Theory In Practice. New York: Basic Books.

[4] Phenix Philip, 1964. Realms of Meaning: Philosophy of The Curriculum of General Education, New York: Mc.Graw-Hill Book Company.

[5] Akbar, Sa'dun. 2011. Revitalisasi Pendidikan Karakter Sekolah Dasar, Naskah Pidato Pengukuhan Guru Besar. Malang: Universitas Negeri Malang.

[6] Akbar, Sa'dun, 2016. Best Practise Pendidikan Karakter SD, Malang: UM Press.

[7] Kemendikbud. 2017. Modul Pelatihan Penguatan Pendidikan Karakter Bagi Komite Sekolah.

[8] Puspitasari,E. 2014. Pendekatan Pendidikan Karakter Jurnal Edueksos Vol III No 2, Juli- Desember 2014 